TITLE:

\title{
Characterization of Bulk and Surface Chemical States on Electrochemically Cycled LiFePO4: A Solid State NMR Study
}

\section{$\operatorname{AUTHOR}(\mathrm{S})$ :}

Shimoda, K.; Sugaya, H.; Murakami, M.; Arai, H.; Uchimoto, Y.; Ogumi, Z.

\section{CITATION:}

Shimoda, K.... [et al]. Characterization of Bulk and Surface Chemical States on Electrochemically Cycled LiFePO4: A Solid State NMR Study. Journal of the Electrochemical Society 2014, 161(6): A1012-A1018

ISSUE DATE:

2014-04-11

URL:

http://hdl.handle.net/2433/189429

RIGHT:

(C) 2014 The Electrochemical Society 


\title{
Characterization of Bulk and Surface Chemical States on Electrochemically Cycled $\mathrm{LiFePO}_{4}$ : A Solid State NMR Study
}

\author{
Keiji Shimoda, ${ }^{\text {a,z }}$ Hidetaka Sugaya, ${ }^{a}$ Miwa Murakami, ${ }^{a}$ Hajime Arai, ${ }^{\text {a, }}$ \\ Yoshiharu Uchimoto, ${ }^{\text {, } * *}$ and Zempachi Ogumi ${ }^{\mathrm{a}, *}$ \\ ${ }^{a}$ Office of Society-Academia Collaboration for Innovation, Kyoto University, Uji, Kyoto 611-0011, Japan \\ ${ }^{b}$ Graduate School of Human and Environment Studies, Kyoto University, Kyoto 606-8501, Japan
}

\begin{abstract}
Bulk and surface chemical states were both investigated for electrochemically delithiated $\mathrm{Li}_{x} \mathrm{FePO}_{4}$ using ${ }^{7} \mathrm{Li}$ and ${ }^{31} \mathrm{P}$ MAS NMR spectroscopy. The quantitative lithium extraction/insertion from $\mathrm{LiFePO}_{4}$ and the reversible two-phase reaction behavior between $\mathrm{LiFePO}_{4}$ and $\mathrm{FePO}_{4}$ were confirmed on electrochemical operation. The ${ }^{7} \mathrm{Li}$ and ${ }^{31} \mathrm{P} \mathrm{NMR}$ spectra of the fully charged $\mathrm{Li}_{x} \mathrm{FePO}_{4}$ evidenced a single $\mathrm{Li}$-poor phase $\mathrm{Li}_{0.05} \mathrm{FePO}_{4}$ instead of a biphasic mixture of $0.05 \mathrm{LiFePO}_{4}$ and $0.95 \mathrm{FePO}_{4}$. Simultaneous growth of $\mathrm{Li}_{x} \mathrm{PO}_{y} \mathrm{~F}_{z}$ was also shown as a surface film component on the charged electrodes, which dynamically increased and decreased in intensity during charging and discharging reactions, respectively. The electrode surface was further characterized with XPS to discuss the surface film formation during electrochemical cycles. Combined chemical state analyzes by NMR and XPS spectroscopies suggested that the degradation of $\mathrm{LiPF}_{6}$ salt occurred from the initial redox cycles, but that of solvent occurred after multiple cycling. The deposition of carbonaceous species would be related to a small capacity fading observed after the multiple charge-discharge cycles.

(C) 2014 The Electrochemical Society. [DOI: 10.1149/2.060406jes] All rights reserved.
\end{abstract}

Manuscript submitted January 16, 2014; revised manuscript received April 2, 2014. Published May 1, 2014.

Lithium iron phosphate $\mathrm{LiFePO}_{4}$ has attracted considerable attention as one of preferred positive electrode materials to be commercialized in large-scale lithium-ion rechargeable batteries (LIB) due to its high theoretical capacity $(170 \mathrm{mAh} / \mathrm{g})$, excellent cycle performance, environmentally low toxicity, and economically low cost. ${ }^{1-8}$ The structure is classified as the olivine-type with a covalent $\left[\mathrm{PO}_{4}\right]^{3-}$ unit. The structural stability on electrochemical cycles is considered to come from the rigid nature of the $\mathrm{FeO}_{6}$ and $\mathrm{PO}_{4}$ polyhedral bonding during delithiation in spite of the volume change of $6.8 \%$ between $\mathrm{LiFePO}_{4}$ and delithiated $\mathrm{FePO}_{4} \cdot{ }^{9}$ Although its inherent low electrical conductivity is known as a common drawback of such polyanion-type cathode materials for LIB use, this can be bypassed by coating the thin-layered carbon on the particle or decreasing the particle size. , $^{, 7,10-14}$

It is very important to understand the structural and chemical changes in $\mathrm{LiFePO}_{4}$ by chemical or electrochemical lithium extraction. The electrochemical charge-discharge curve shows a flat plateau at a potential of $\sim 3.45 \mathrm{~V} \mathrm{vs} \mathrm{Li} / \mathrm{Li}^{+}$over a wide compositional range between $\mathrm{LiFePO}_{4}$ and $\mathrm{FePO}_{4}$, suggesting that the delithiation reaction basically proceeds on two-phase mechanism by varying the $\mathrm{LiFePO}_{4} / \mathrm{FePO}_{4}$ ratio in the nominal composition $\mathrm{Li}_{x} \mathrm{FePO}_{4}$. The first report by Padhi et al. indicated the coexistence of $\mathrm{LiFePO}_{4}$ and $\mathrm{FePO}_{4}$ in the partially delithiated $\mathrm{Li}_{x} \mathrm{FePO}_{4}$ by using X-ray diffraction (XRD). ${ }^{1} \mathrm{X}$-ray absorption near edge structure (XANES) spectra at $\mathrm{Fe}$ $K$-edge showed a peak shift to higher energy, which indicates a continuous increase in $\mathrm{Fe}^{3+} /\left(\mathrm{Fe}^{2+}+\mathrm{Fe}^{3+}\right)$ ratio with lithium extraction. ${ }^{15-17}$ Based on the detailed Rietveld analyses of the neutron diffraction pattern for a chemically delithiated $\mathrm{Li}_{0.5} \mathrm{FePO}_{4}$, Yamada et al. have suggested the presence of solid solution phases $\mathrm{Li}_{\alpha} \mathrm{FePO}_{4}$ and $\mathrm{Li}_{1-\beta} \mathrm{FePO}_{4}$ at room temperature, which are close to stoichiometric end-members $\mathrm{FePO}_{4}$ and $\mathrm{LiFePO}_{4}$, respectively. ${ }^{18}$ Subsequent studies revealed that the compositional range where the end-member solid solution phase $\mathrm{Li}_{\alpha} \mathrm{FePO}_{4}$ or $\mathrm{Li}_{1-\beta} \mathrm{FePO}_{4}$ exists as a single phase varies with particle size and synthesis temperature. ${ }^{19}$ Meethong et al. have reported that the miscibility gap between $\mathrm{Li}_{\alpha} \mathrm{FePO}_{4}$ and $\mathrm{Li}_{1-\beta} \mathrm{FePO}_{4}$ became narrower with decreasing the particle size down to less than $40 \mathrm{~nm} \cdot{ }^{20} \mathrm{~A}$ high temperature XRD study indicated a single solid solution phase of $\mathrm{Li}_{x} \mathrm{FePO}_{4}$ over the entire compositional range $(0 \leq x \leq 1)$ above $450^{\circ} \mathrm{C}^{21}$

Solid state nuclear magnetic resonance (NMR) spectroscopy is a useful technique for investigating the chemical environments

\footnotetext{
${ }^{*}$ Electrochemical Society Active Member.
}

${ }^{\text {z} E-m a i l: ~ k-s h i m o d a @ s a c i . k y o t o-u . a c . j p ~}$ on a specific element in the battery materials. ${ }^{6}{ }^{7} \mathrm{Li}$ magic-angle spinning (MAS) NMR technique has been widely applied for the chemical structure characterization of the pristine and partially delithiated cathode materials, because it gives direct information about mobile $\mathrm{Li}^{+}$ions. ${ }^{2-33}$ Earlier ${ }^{7} \mathrm{Li}$ MAS NMR studies revealed that the strong dipolar interaction between Li nuclei and paramagnetic spins on transition metals produces a severe signal broadening with sideband manifolds. Kim et al. reported the ${ }^{7} \mathrm{Li}$ MAS NMR spectra of the pristine and electrochemically lithium extracted/reinserted $\mathrm{LiFePO}_{4}$ nanoplates. ${ }^{7}$ They showed the decrease/increase in intensity of the $\mathrm{LiFePO}_{4}$ signal with lithium extraction/insertion, respectively. Furthermore, ${ }^{7} \mathrm{Li}$ MAS NMR was found to be useful for acquiring signals from the diamagnetic lithium salt deposited on the surface of electrode materials, which will be a key information to evaluate the capacity fading in the operating battery. ${ }^{34-40}$ Very recently, Cuisinier et al. have monitored the interphase forming on the $\mathrm{LiFePO}_{4}$ electrode and quantitatively examined its evolution upon electrochemical cycling. ${ }^{41}$

Several researchers have shown that ${ }^{31} \mathrm{P}$ MAS NMR is a good measure of the structural changes in the host framework of $\mathrm{LiFePO}_{4}$ upon lithium removal. ${ }^{42,43}{ }^{31} \mathrm{P} \mathrm{NMR}$ signals of $\mathrm{LiFePO}_{4}$ and $\mathrm{FePO}_{4}$ are strongly governed by the Fermi contact interaction as well as the dipolar interaction mentioned above. ${ }^{42-45}$ The ${ }^{31} \mathrm{P}$ MAS NMR spectrum of a chemically delithiated $\mathrm{Li}_{0.5} \mathrm{FePO}_{4}$ represented the mixture of $\mathrm{LiFePO}_{4}$ and $\mathrm{FePO}_{4}$ signals, indicating its biphasic behavior at room temperature. ${ }^{43}$ Solid solution behavior of the partially delithiated $\mathrm{Li}_{x} \mathrm{FePO}_{4}$ after or during heat-treatment has been also investigated with the aid of ${ }^{31} \mathrm{P}$ NMR. ${ }^{42,43}$ Many of these studies focus on the structural or spectral changes in the chemically delithiated $\mathrm{LiFePO}_{4}$, and give useful information to understand the essential mechanism of $\mathrm{Li}$ extraction from its host structure. However, it is likely that the electrochemical delithiation involves complicated reactions including side reactions between the electrode and electrolyte solution during multiple charge-discharge cycles. Quantitative examination of such whole expected and unexpected reactions gives much more important information upon the practical battery operations. As indicated above, solid state NMR spectroscopy will be a best choice to simultaneously obtain the bulk and surface information for the electrode materials in a quantitative manner. For this purpose, we examined the local structural changes in the $\mathrm{LiFePO}_{4} / \mathrm{FePO}_{4}$ host framework and its surface alterations on lithium extraction process for the electrochemically prepared $\mathrm{Li}_{x} \mathrm{FePO}_{4}$ samples by using ${ }^{7} \mathrm{Li}$ and ${ }^{31} \mathrm{P}$ MAS NMR spectroscopy. X-ray photoelectron spectroscopy (XPS) measurements were also performed to obtain the complementary information about electrode surface modification on charge-discharge cycles. 


\section{Experimental}

In this study, we used the commercial $\mathrm{LiFePO}_{4}$ powder (Mitsui Engineering \& Shipbuilding Co., Ltd.), which is $\sim 460 \mathrm{~nm}$ in particle size and carbon-coated $(1.2 \mathrm{wt} \%)$ for improving electrical conductivity. A mixture of $\mathrm{LiFePO}_{4}$ powder, acetylene black (Denki kagaku Kogyo), polyvinylidene difluoride (PVDF, Kureha) with a weight ratio of 70:15:15 was spread with N-methylpyrrolidone (NMP) onto aluminum foil, and then dried at $80^{\circ} \mathrm{C}$ under vacuum overnight to constitute a positive electrode. The electrode was cut with the dimensions of $25 \mathrm{~mm} \times 15 \mathrm{~mm}$, which included $\sim 10 \mathrm{mg}$ of $\mathrm{LiFePO}_{4}$. A foil of metallic lithium $(0.2 \mathrm{~mm}$ in thickness, $>99.9 \%$, Honjo Metal) was used as counter and reference electrodes. The electrolyte used in this study was $1 \mathrm{M} \mathrm{LiPF}_{6}$ dissolved in anhydrous ethylene carbonate (EC) and ethylmethyl carbonate (EMC) with a volumetric ratio of 3:7 (Kishida Chemical). These components were assembled together with the Celgard 2500 separator and soaked in the electrolyte solution in an Ar-filled glove box ( $<3.0 \mathrm{ppm}$ oxygen), which were sealed in Al-coated plastic bag cells.

The electrochemical measurements were performed at room temperature on an automatic cycling/data recording system (HJ1001SD8, Hokuto Denko). The cells were galvanostatically cycled over the potential range from $2.5 \mathrm{~V}$ to $4.0 \mathrm{~V}$ at a rate of $\mathrm{C} / 5(34.0 \mathrm{~mA} / \mathrm{g})$. The charging process included a 30 -min constant voltage process at $4.0 \mathrm{~V}$ prior to the discharging. After the 3-cycle charge-discharge processes to confirm the capacities of the assembled cells, the cells were further charged or subsequently discharged to the desired $x$ in the bulk composition $\mathrm{Li}_{x} \mathrm{FePO}_{4}$. Some cells were cycled another 10 and 50 times to examine the cycle performance and possible structural alterations upon multiple cycles. Two or three cells were prepared to confirm the reproducibility of the experiments. Fig. 1 shows a representative charge-discharge profile and discharge capacity performance up to $51^{\text {st }}$ cycle. The electrode samples soaked in the electrolyte solution for $48 \mathrm{~h}$ and $\sim 7$ months at room temperature, but not electrochemically cycled, were also prepared for reference. The prepared samples were listed in Table I. The cells were relaxed for several hours after the electrochemical procedures. They were carefully disassembled in the Ar-filled glove box, and the $\mathrm{LiFePO}_{4}$ electrodes were rinsed with dimethyl carbonate (DMC) to remove the electrolyte solution residue. The electrode samples were then used for XPS and XRD measurements, which were scratched off from the Al current collector for NMR measurements.

The ${ }^{7} \mathrm{Li}$ and ${ }^{31} \mathrm{P}$ MAS NMR measurements were performed on a JNM-ECA600 spectrometer (JEOL Ltd.) at a magnetic field of $14.1 \mathrm{~T}$ ( ${ }^{7} \mathrm{Li}$ and ${ }^{31} \mathrm{P}$ working frequency; 233.2 and $243.0 \mathrm{MHz}$, respectively).

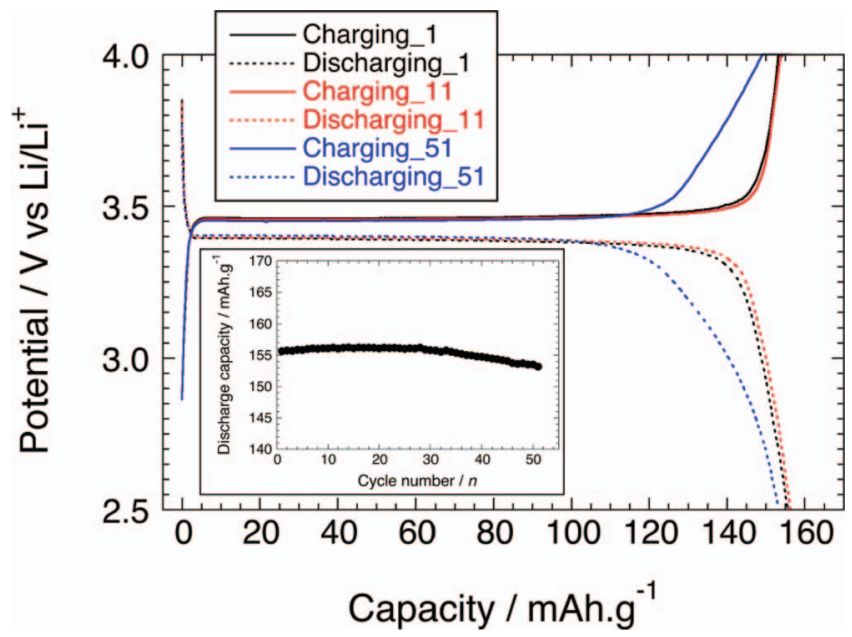

Figure 1. A representative charge-discharge curve on the $1^{\text {st }}, 11^{\text {th }}$, and $51^{\text {st }}$ cycles for a $\mathrm{Li} / / \mathrm{LiFePO}_{4}$ cell obtained at $\mathrm{C} / 5$ rate, and its capacity performance on discharging cycles (inset).
Table I. Lithium contents in $\mathrm{Li}_{x} \mathrm{FePO}_{4}(0 \leq x \leq 1)$ samples estimated from the electrochemical and ex situ ${ }^{7} \mathrm{Li}$ MAS NMR measurements.

\begin{tabular}{lcc} 
& Electrochemical & ${ }^{7} \mathrm{Li} \mathrm{NMR}$ \\
\hline Soaked & $(1.00)$ & 1.00 \\
Soaked for 7 months & $(1.00)$ & 0.97 \\
Charged to 17.0 mAh/g & 0.90 & 0.86 \\
Half charged & 0.54 & 0.50 \\
Charged to $144.5 \mathrm{mAh} / \mathrm{g}$ & 0.15 & 0.11 \\
Full charged & 0.09 & $0.06[0.05]$ \\
Half discharged & 0.56 & 0.52 \\
Full discharged & 1.00 & 0.99 \\
Full charged_11 cycle & 0.07 & $0.06[0.05]$ \\
Half discharged_11 cycle & 0.55 & 0.53 \\
Full discharged_11 cycle & 1.00 & 0.92 \\
Full charged_51 cycle & 0.08 & $0.09[0.07]$ \\
Full discharged_51 cycle & 0.99 & 0.99
\end{tabular}

The standard deviation in NMR quantification was roughly estimated to be less than 0.02 from two or three different samples.

The ${ }^{7} \mathrm{Li}$ signal components attributable to the lithium salt degradation (chemical shift at $\sim 0 \mathrm{ppm}$ and its spinning sidebands) are also included in the quantification with a relaxation delay of $0.1 \mathrm{~s}$. The Li contents in the Li-poor solid solution phase $\mathrm{Li}_{\alpha} \mathrm{FePO}_{4}$ are shown in square brackets.

The powder samples were packed into $1.6 \mathrm{~mm} \phi$ MAS $\mathrm{ZrO}_{2}$ rotors with airtight caps, which were spun at a spinning rate of $35 \mathrm{kHz}$ during the experiments. Fast MAS ${ }^{7} \mathrm{Li}$ NMR spectra were also acquired at a spinning rate of $60 \mathrm{kHz}$ with a wide-bore T3 probe (Agilent Technologies Inc.) and $1.2 \mathrm{~mm} \phi$ MAS rotors. Although all the experiments were nominally carried out at room temperature, the practical temperatures of spinning samples at $35 \mathrm{kHz}$ were estimated to be $\sim 60^{\circ} \mathrm{C}$, due to frictional heating, based on a separate temperature calibration using ${ }^{207} \mathrm{~Pb}$ NMR for $\mathrm{Pb}\left(\mathrm{NO}_{3}\right)_{2}$. A rotor-synchronized Hahn echo sequence $(\pi / 2-\tau-\pi-\tau$-acq.) was used with a $\pi / 2$ pulse width of $1.0 \mu \mathrm{s}$ and a relaxation delay of $0.1 \mathrm{~s}$ for both the ${ }^{7} \mathrm{Li}$ and ${ }^{31} \mathrm{P}$ experiments. $\mathrm{LiCoO}_{2}$ and $\left(\mathrm{NH}_{4}\right) \mathrm{H}_{2} \mathrm{PO}_{4}$ powders were used as ${ }^{7} \mathrm{Li}$ and ${ }^{31} \mathrm{P}$ chemical shift solid references at 0.0 and $0.9 \mathrm{ppm}$, respectively. Previous studies have shown that the ${ }^{31} \mathrm{P}$ NMR signals for $\mathrm{Li}_{x} \mathrm{FePO}_{4}$ extended in a wide resonance frequency and it was difficult to excite the whole signal simultaneously. Alternatively, the variable offset cumulative spectrum (VOCS) technique was applied, ${ }^{42,45}$ where a suite of spectra was accumulated at each irradiation frequency with an offset step of $\sim 120 \mathrm{kHz}$, and then summed up to obtain a single undistorted wide signal.

The XPS spectra were collected on a PHI Quantera SXM (ULVACPHI, Inc) using a monochromatized $\mathrm{Al} K \alpha$ radiation at $1486.6 \mathrm{eV}$ for uncycled and multiply-cycled electrode samples. Small pieces of electrodes were mounted on a sample holder in the Ar-filled glove box, which were then transferred into the XPS ultrahigh vacuum chamber to avoid undesirable surface contamination by atmospheric oxygen and moisture. The analyzed area of the sample surface was $0.1 \mathrm{~mm} \times 0.1 \mathrm{~mm}$ in dimension. Spectra were recorded with a constant pass energy of $55 \mathrm{eV}$ without external charge neutralization. The binding energy scale was calibrated from a main $\mathrm{C} 1 \mathrm{~s}$ peak in the electrode $(284.3 \mathrm{eV})$. Core peaks were analyzed after the Shirley-type background subtraction.

\section{Results and Discussion}

Spectral evolution of $\mathrm{LiFePO}_{4}$ during the charge-discharge cycle.- ${ }^{7} \mathrm{Li}$ MAS NMR spectra for $\mathrm{LiFePO}_{4}$ electrodes disassembled at various states of charge (SOC) after the 3 -cycle pre-processing were shown in Fig. 2. The intensities were normalized for the sample weights. The ${ }^{7} \mathrm{Li}$ isotropic shift was estimated at $-27 \mathrm{ppm}$, which is close to the resonance reported by Hamelet et al. ${ }^{4}$ It should be noted that the signal included significant spinning sideband manifolds at 


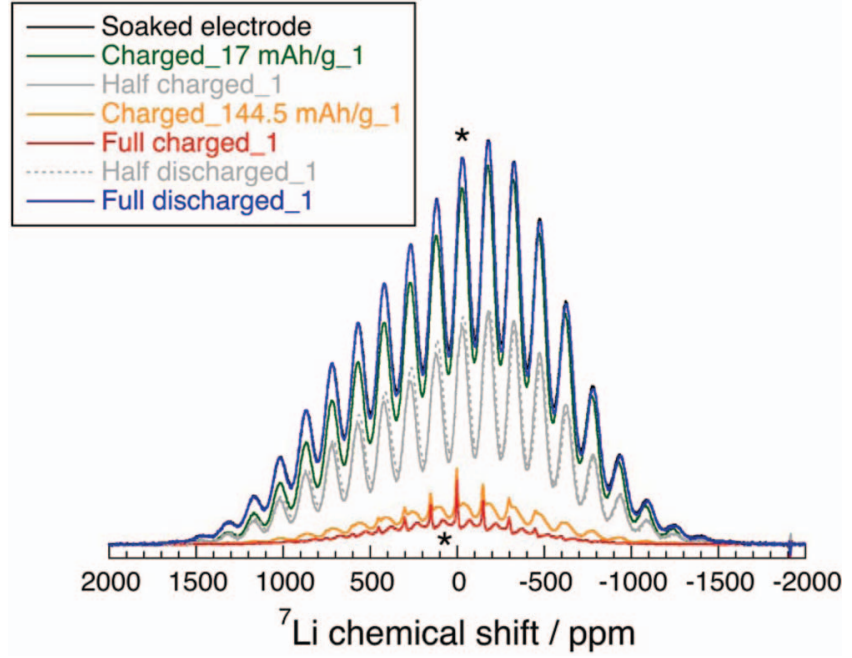

Figure 2. ${ }^{7} \mathrm{Li}$ MAS NMR spectra of the $\mathrm{LiFePO}_{4}$ electrodes disassembled at various states of charge during an initial cycle. Asterisks indicate the isotropic shifts and the other peaks are their spinning sidebands.

a relatively high magnetic field $\left(600 \mathrm{MHz}\right.$ at ${ }^{1} \mathrm{H}$ frequency) and a moderate spinning speed $(35 \mathrm{kHz})$. The severe signal broadening and sideband manifolds arise from the strong dipolar interaction between paramagnetic spins and Li nuclei, ${ }^{30}$ which could not be totally canceled out at the spinning condition in this study. With decreasing $x$ to $\sim 0.15$ (corresponding to the charging of $144.5 \mathrm{mAh} / \mathrm{g}$ ) in $\mathrm{Li}_{x} \mathrm{FePO}_{4}$, the signal monotonously decreased in intensity without any observable shift in position. This suggests that the local environment around $\mathrm{Li}$ does not change with the removal of $\mathrm{Li}^{+}$ions, which seems to support the simple biphasic behavior of $\mathrm{LiFePO}_{4}$ and $\mathrm{FePO}_{4}$ in the partially delithiated $\mathrm{Li}_{x} \mathrm{FePO}_{4}{ }^{1,9}$ Table I indicates that the Li contents in $\mathrm{LiFePO}_{4}$ electrodes evaluated from ${ }^{7} \mathrm{Li}$ NMR are in reasonable agreement with those from electrochemical measurements. It was clearly shown that the fully charged electrode sample still contained unreactive $\mathrm{Li}$ of $\sim 5 \%$ (NMR-based). We should emphasize that the spectrum of the fully charged sample was very different in shape from the others; the fully charged $\mathrm{Li}_{x} \mathrm{FePO}_{4}$ did show a distinct isotropic shift at $77 \mathrm{ppm}$ with the sideband manifolds different from those in the partially or fully lithiated samples (Fig. 3). This fact strongly suggests that the Li environments in the charged state are different from those in pristine $\mathrm{LiFePO}_{4}$, and it can be ruled out that this remaining ${ }^{7} \mathrm{Li}$ signal comes from unreacted $\mathrm{LiFePO}_{4}$ particles isolated from electron

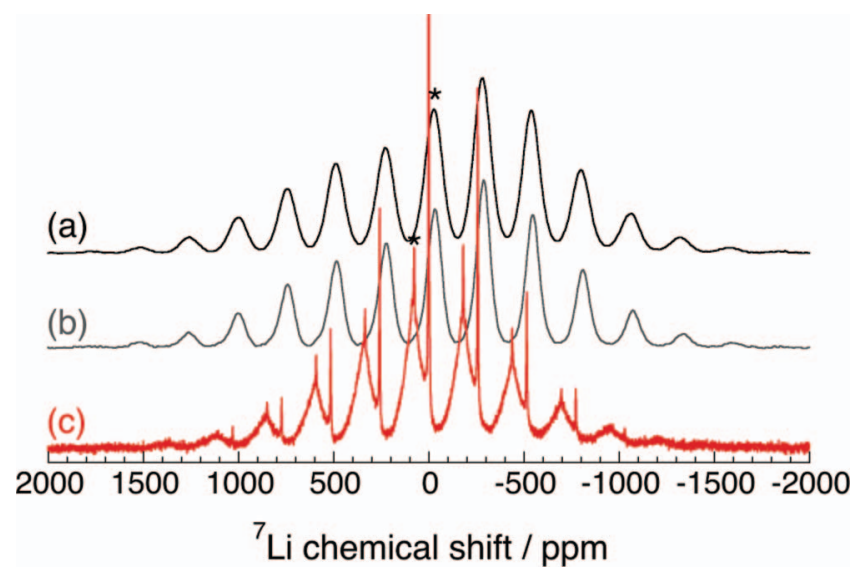

Figure 3. ${ }^{7} \mathrm{Li}$ MAS NMR spectra of the $\mathrm{LiFePO}_{4}$ electrodes disassembled at various states of charge during an initial cycle; (a) soaked, (b) half charged, and (c) fully charged electrodes. Samples were spun at a rate of $60 \mathrm{kHz}$. Intensities were rescaled and vertically shifted for clarity. conductive path in the composite electrode. The presence of a minor impurity phase in the pristine $\mathrm{LiFePO}_{4}$ was also preclusive. The ${ }^{7} \mathrm{Li}$ isotropic shift at $77 \mathrm{ppm}$ can be explained by the stronger hyperfine interaction between $\mathrm{Li}$ nuclei and its nearby paramagnetic spins on $\mathrm{Fe}^{3+}$ in $\mathrm{FePO}_{4}$ compared to $\mathrm{Fe}^{2+}$ in $\mathrm{LiFePO}_{4}$, because $\mathrm{Fe}^{3+}$ has the higher electron spin $S=5 / 2$ in high-spin state compared to $\mathrm{Fe}^{2+}$ in $\mathrm{LiFePO}_{4}(S=2)$. This situation is comparable to olivine $\mathrm{LiMnPO}_{4}$ where $\mathrm{Mn}^{2+}$ has the isoelectronic configuration $\left(\mathrm{t}_{2 \mathrm{~g}}{ }^{3} \mathrm{e}_{\mathrm{g}}{ }^{2}, S=5 / 2\right)$ with $\mathrm{Fe}^{3+}$ in $\mathrm{FePO}_{4}$, and it shows an isotropic shift at 57-75 ppm. ${ }^{28,43,44,46}$ It is also interesting to note that the residual $\mathrm{Li}$ content in the fully charged $\mathrm{Li}_{x} \mathrm{FePO}_{4}$ was close to the end-member solid solution composition $\mathrm{Li}_{0.05} \mathrm{FePO}_{4}$ reported by Yamada et al. ${ }^{18}$ We therefore concluded that the signal could be assigned to the Li environment close to $\mathrm{Fe}^{3+}$ in the $\mathrm{Li}$-poor solid solution phase $\mathrm{Li}_{\alpha} \mathrm{FePO}_{4}$ (Here, $\alpha \approx 0.05-0.07$ in this study). We emphasize that this is a first direct evidence of $\mathrm{Li}$ residing in $\mathrm{Li}_{\alpha} \mathrm{FePO}_{4}$, which had been ambiguously evaluated based on lattice parameters with Vegard's law or from Li occupancy refinements in neutron diffraction Rietveld analysis. ${ }^{18,19}$ Close inspection of Figure 3 showed that the isotropic shift at $77 \mathrm{ppm}$ had two components; broad and sharp ones with their peak tops almost identical. The broad and sharp components had the full width at half maxima (FWHM) of $27 \mathrm{kHz}$, which was close to that in $\mathrm{LiFePO}_{4}(25 \mathrm{kHz})$, and $1.5 \mathrm{kHz}$, respectively. The sharp component was observed for all the $\mathrm{Li}_{\alpha} \mathrm{FePO}_{4}$ samples. Although a further study should be done for its complete assignment, it may be reasonable to consider that these two components come from the $\mathrm{Li}$ ions with similar local environments but different mobilities, where the highly mobile Li ion gives the sharp peak. This may imply that some Li ions (less than $5 \%$ of total $\mathrm{Li}$ in $\mathrm{Li}_{\alpha} \mathrm{FePO}_{4}$ ) diffuse faster in $\mathrm{Li}_{\alpha} \mathrm{FePO}_{4}$ solid solution phase. Contrary to the Li-poor region, a spectral evidence of Li-rich solid solution phase $\mathrm{Li}_{1-\beta} \mathrm{FePO}_{4}$, if present, was not confirmed. A small amount of $\mathrm{Fe}^{3+}$ would give less influence on ${ }^{7} \mathrm{Li}$ signal. It should be noted that the spectrum of the deeply charged $\mathrm{Li}_{x} \mathrm{FePO}_{4}$ samples have an additional sharp signal centered at $-0.3 \mathrm{ppm}$ with up to $4^{\text {th }}$ order sidebands. This signal can be assigned to the diamagnetic lithium salt species that can be attributed to the surface film closely contacted with the $\mathrm{Li}_{x} \mathrm{FePO}_{4}$ particles. ${ }^{36,41}$ The evolution of the diamagnetic signal will be discussed later.

${ }^{31}$ P MAS NMR spectra of the $\mathrm{Li}_{x} \mathrm{FePO}_{4}$ samples provide additional information (Fig. 4). $\mathrm{LiFePO}_{4}$ showed a very broad ${ }^{31} \mathrm{P}$ signal ranging from 2000 to $5000 \mathrm{ppm}$. Again, it should be noted that the severe signal broadening arises from the strong dipolar interaction between paramagnetic spins and $\mathrm{P}$ nuclei. The isotropic shift was estimated to

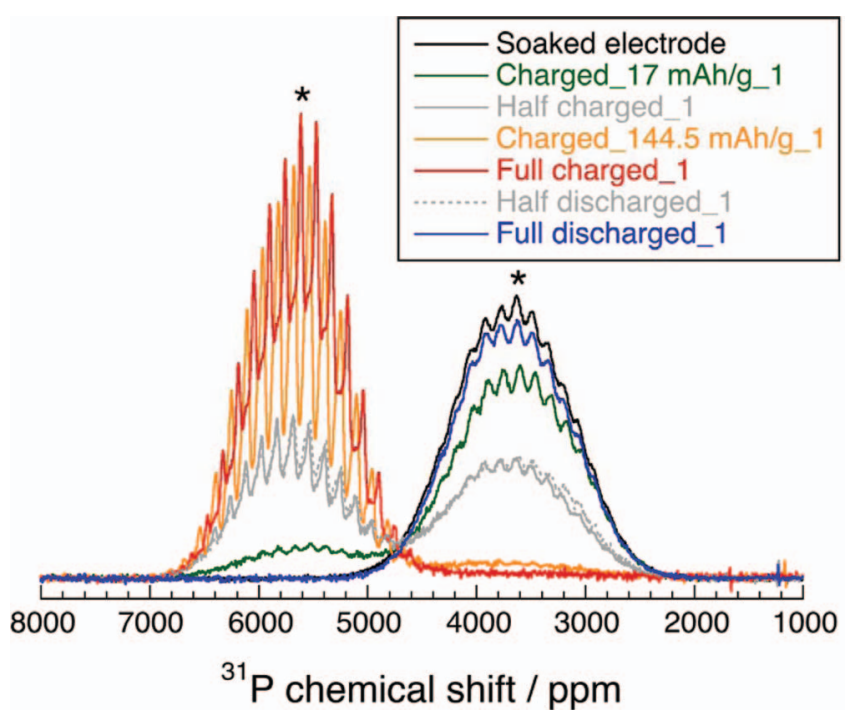

Figure 4. ${ }^{31} \mathrm{P}$ MAS NMR spectra of the $\mathrm{LiFePO}_{4}$ electrodes disassembled at various states of charge during an initial cycle. Asterisks indicate the isotropic shifts and the other peaks are their spinning sidebands. 
be 3630 ppm by varying sample spinning rates with the temperature scaling procedure. ${ }^{45}$ The obtained value was close to the one reported by Clément et al. ${ }^{46}$ This signal decreased in intensity with the lithium removal from $\mathrm{LiFePO}_{4}$, and a new broad signal grew up concurrently at between 4500 and 7000 ppm, which can be attributed to $\mathrm{FePO}_{4}$. The isotropic shift for the $\mathrm{FePO}_{4}$ component (5610 ppm) was lower than the previous studies $(\sim 5800 \mathrm{ppm})^{42,43}$ due to the frictional heating induced by sample spinning that moves the paramagnetic shift to lower frequency. ${ }^{45}$ The $\mathrm{Li}_{\sim 0.5} \mathrm{FePO}_{4}$ samples have two broad signals with almost same peak area ratios, again supporting that $\mathrm{Li}_{x} \mathrm{FePO}_{4}$ is expressed as a mixture of $\mathrm{LiFePO}_{4}$ and $\mathrm{FePO}_{4}$. Recently, the lithium staging phenomenon was reported in an electrochemically delithiated $\mathrm{Li}_{\sim 0.5} \mathrm{FePO}_{4}$ nanowire sample with aberration-corrected annularbright-field scanning transmission electron microscopy (ABF-STEM) technique. ${ }^{47}$ This lithium staging structure means the existence of a single solid solution phase $\mathrm{Li}_{0.5} \mathrm{FePO}_{4}$, which is in contrast with the previous XRD and the present NMR studies. ${ }^{1,9,18,48}$ The staging structure expects a ${ }^{31} \mathrm{P}$ NMR shift intermediate between those of $\mathrm{LiFePO}_{4}$ and $\mathrm{FePO}_{4}(3000-6000 \mathrm{ppm}),{ }^{42,46}$ while it was not observed in this study (Fig. 4). Such a discrepancy would be related to the particle size used in these studies. Particle downsizing less than $\sim 50 \mathrm{~nm}$ may cause the successful observation of the single solid solution phase in $\mathrm{Li}_{0.5} \mathrm{FePO}_{4}$. The fully charged electrode shows a single broad signal of $\mathrm{FePO}_{4}$. We note that the $\mathrm{FePO}_{4}$ signal of the fully charged sample was slightly different in peak position from that of the partially delithiated ones. This could be also associated with the end-member solid solution $\mathrm{Li}_{\alpha} \mathrm{FePO}_{4}$, which may have a slightly different $\mathrm{P}$ environment from the $\mathrm{FePO}_{4}$ component in $\mathrm{Li}_{\sim 0.5} \mathrm{FePO}_{4}$ and $\mathrm{Li}_{0.15} \mathrm{FePO}_{4}$. The fully discharged $\mathrm{Li}_{x} \mathrm{FePO}_{4}$ showed a similar spectrum to $\mathrm{LiFePO}_{4}$. The previous study on $\mathrm{P}$ K-edge XANES spectra for $\mathrm{Li}_{x} \mathrm{FePO}_{4}$ at various $\mathrm{Li}$ contents reported a small change at pre-edge peak, which was ascribed to the evolution in electronic orbital hybridization between $\mathrm{P} 2 \mathrm{p}$ and Fe $3 \mathrm{~d}$ states through the shared $\mathrm{O}$ atom with increasing the oxidation state of Fe ions. ${ }^{49}$ We re-emphasize that although the steric change in $\left[\mathrm{PO}_{4}\right]^{3-}$ molecular unit is not significant as suggested by XRD and $\mathrm{XAS},{ }^{31} \mathrm{P}$ NMR provides a much larger difference in shift position between $\mathrm{LiFePO}_{4}$ and $\mathrm{FePO}_{4}$ due to the difference in transferred spin density on $\mathrm{P}$ nuclei through the intervening $\mathrm{O}$ atoms. This indicates that ${ }^{31} \mathrm{P}$ NMR is sensitive to the change in the degree of hybridization (covalency) in $\left[\mathrm{PO}_{4}\right]^{3-}$, which observation is especially enhanced by the presence of paramagnetic spins. ${ }^{45}$

Fig. 5 represents the ${ }^{7} \mathrm{Li}$ spectra of $\mathrm{LiFePO}_{4}$ electrodes after 1, 11, and 51 times charging and subsequent discharging along with uncycled (soaked) $\mathrm{LiFePO}_{4}$. The spectra of the fully discharged $\mathrm{Li}_{x} \mathrm{FePO}_{4}$

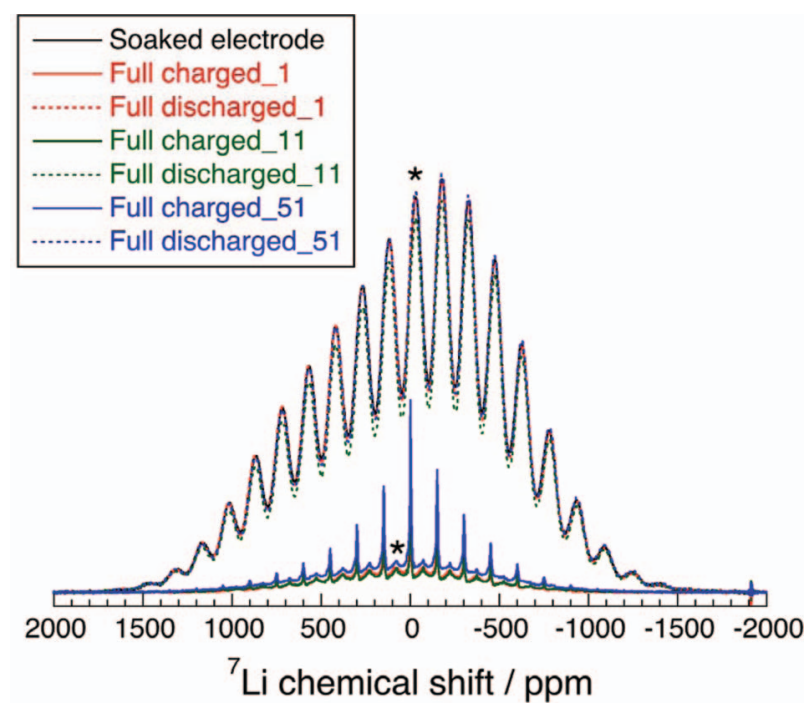

Figure 5. ${ }^{7} \mathrm{Li}$ MAS NMR spectra of the $\mathrm{LiFePO}_{4}$ electrodes disassembled on $1^{\mathrm{st}}, 11^{\mathrm{th}}$, and $51^{\mathrm{st}}$ cycles.

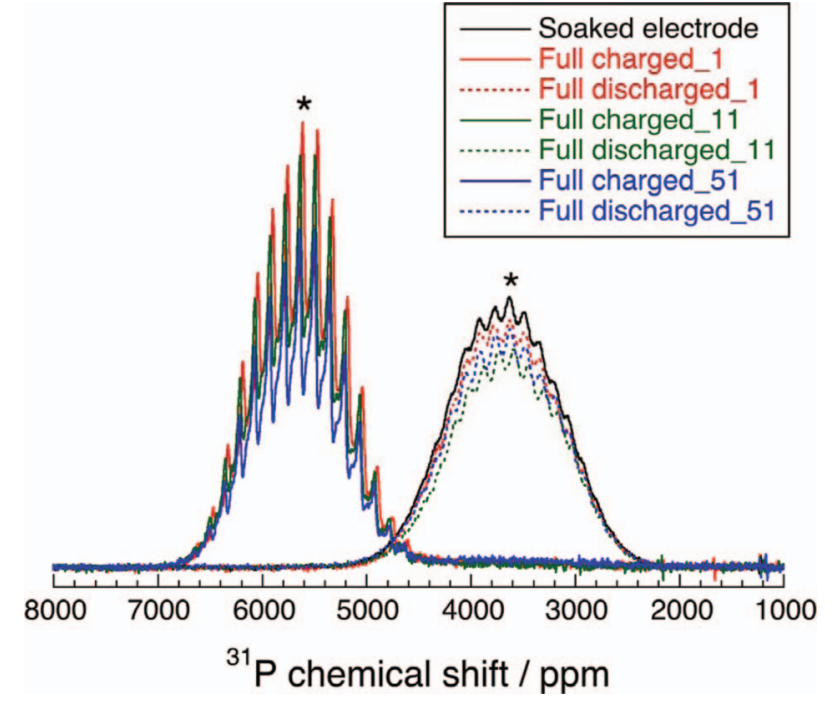

Figure 6. ${ }^{31} \mathrm{P}$ MAS NMR spectra of the $\mathrm{LiFePO}_{4}$ electrodes disassembled on $1^{\text {st }}, 11^{\text {th }}$, and $51^{\text {st }}$ cycles.

cycled 1, 11, 51 times were almost identical in shape and position to the uncycled $\mathrm{LiFePO}_{4}$. The fully charged $\mathrm{Li}_{x} \mathrm{FePO}_{4}$ cycled 1, 11, 51 times were also identical to each other and did show the broad signal overlapped by the sharp diamagnetic lithium signals. The corresponding ${ }^{31} \mathrm{P}$ spectra of the multiply-cycled $\mathrm{Li}_{x} \mathrm{FePO}_{4}$ support the ${ }^{7} \mathrm{Li}$ results (Fig. 6); the fully discharged electrodes were similar in shape to the uncycled $\mathrm{LiFePO}_{4}$, although their intensities were lower than the latter. Also, the charged samples showed similar spectra to each other. These results suggest that the local structures around $\mathrm{Li}$ and $\mathrm{P}$ atoms are stable in $\mathrm{LiFePO}_{4}$ and $\mathrm{FePO}_{4}\left(\mathrm{Li}_{\alpha} \mathrm{FePO}_{4}\right.$ in a precise sense) with respect to lithium extraction/insertion cycles, which would be a reason of its good cycle performance. This is in sharp contrast with $\mathrm{LiMn}_{2} \mathrm{O}_{4}$ spinel, in which case the drastic changes in ${ }^{7} \mathrm{Li}$ signal coming from the host structure have been reported along with its poor capacity retention..$^{50}$

Evolution of the diamagnetic surface species.- Another significant evolution was observed on the diamagnetic lithium salt signal centered at $-0.3 \mathrm{ppm}$. This peak grew up with increasing charging cycle from $1^{\text {st }}$ to $51^{\text {st }}$ cycle. It was also observed in the $\mathrm{LiFePO}_{4}$ electrode soaked in electrolyte solution for 7 months at room temperature. Fig. 7 shows a differential spectrum of the $51^{\text {st }}$-cycled charging

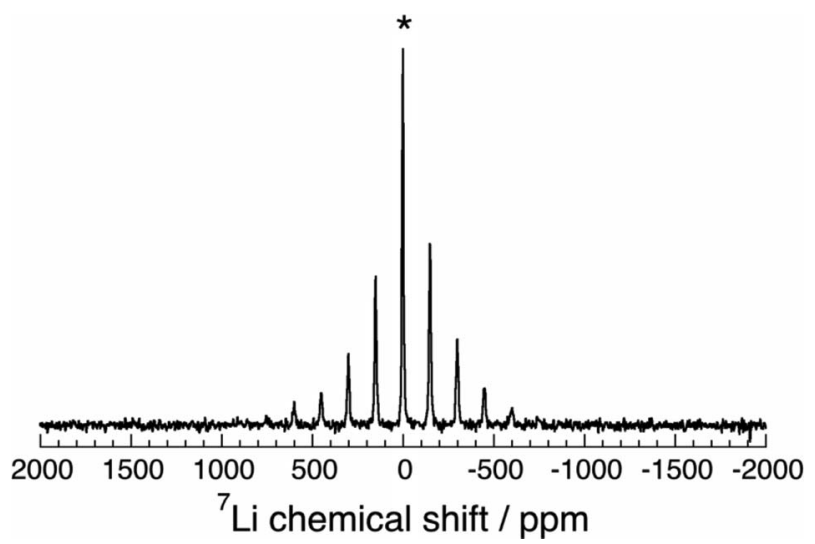

Figure 7. ${ }^{7} \mathrm{Li}$ MAS NMR spectrum of a diamagnetic lithium component for the $\mathrm{LiFePO}_{4}$ electrode disassembled after $51^{\text {th }}$ charging obtained by subtracting the two spectra acquired with the relaxation delays of 20 and $0.1 \mathrm{~s}$. An asterisk indicates the isotropic shift. 


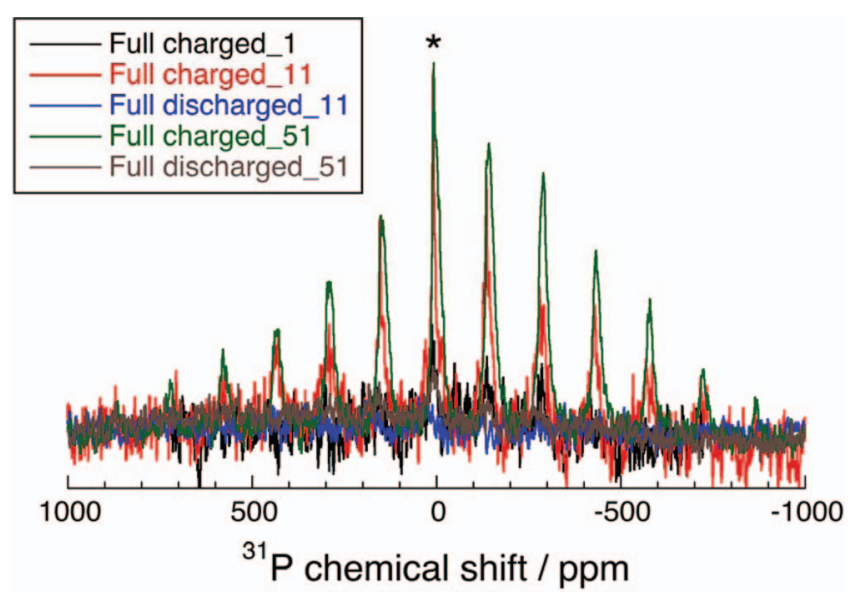

Figure 8. ${ }^{31} \mathrm{P}$ MAS NMR spectra of a diamagnetic phosphorous component for the $\mathrm{LiFePO}_{4}$ electrodes disassembled on $1^{\text {st }}, 11^{\text {th }}$, and $51^{\text {st }}$ cycles. An asterisk indicates the isotropic shift.

spectrum with relaxation delays of $0.1 \mathrm{~s}$ and $20 \mathrm{~s}$, which exclusively represents the diamagnetic lithium component with significant sideband manifolds. The spectra with the delays of $>20 \mathrm{~s}$ did not change their signal intensities. This indicates that the full representation of the ${ }^{7} \mathrm{Li}$ signal of $\mathrm{Li}_{x} \mathrm{FePO}_{4}$ is sufficient with a delay of $0.1 \mathrm{~s}$, but that of the diamagnetic species needs $20 \mathrm{~s}$. It is interesting to note that the diamagnetic signal disappeared in the subsequent discharging processes (Fig. 5). Cuisinier et al. have reported a similar dynamic behavior of the diamagnetic signal with charge-discharge process. ${ }^{41}$ They showed that the lithium containing diamagnetic species detected by NMR underwent a process of dissolution at low potentials and precipitation at high potentials that can be seen as a reversible breathing process.

${ }^{31} \mathrm{P}$ MAS NMR spectra of the $\mathrm{LiFePO}_{4}$ electrodes after 1,11 , and 51 times charging and subsequent discharging were shown in Fig. 8, in the spectral region from -1000 to $1000 \mathrm{ppm}$. The overall spectral shape was similar to those reported by Cuisinier et al., although the isotropic shift was slightly higher in frequency $(\sim 8 \mathrm{ppm})$ and close to that of $\mathrm{Li}_{3} \mathrm{PO}_{4}(10.8 \mathrm{ppm})$, indicating that this signal is attributable to a diamagnetic phosphate component. The relatively broad signal having a tail to lower frequency suggests its low crystalline nature on the thin surface of $\mathrm{Li}_{x} \mathrm{FePO}_{4}$ particles and/or the presence of a variety of $\mathrm{Li}_{x} \mathrm{PO}_{y} \mathrm{~F}_{z}$ components. ${ }^{41,51,52}$ We note that the ${ }^{31} \mathrm{P}$ MAS NMR spectra of the diamagnetic component also showed an increase in intensity with multiple charging process and decrease with subsequent discharging, similar to the above-mentioned dynamic behavior of the ${ }^{7} \mathrm{Li}$ signal. This strongly suggests that the diamagnetic species observed both on the ${ }^{7} \mathrm{Li}$ and ${ }^{31} \mathrm{P}$ NMR can be assigned to the identical material, $\mathrm{Li}_{x} \mathrm{PO}_{y} \mathrm{~F}_{z}$, which is considered to be a decomposition product of the $\mathrm{LiPF}_{6}$ salt. ${ }^{51,52} \mathrm{The} \mathrm{Li} / \mathrm{P}$ content in $\mathrm{Li}_{x} \mathrm{PO}_{y} \mathrm{~F}_{z}$ was estimated to be $0.006 / 0.001,0.012 / 0.004$ and $0.018 / 0.006$ at $1^{\text {st }}, 11^{\text {th }}$ and $51^{\text {st }}$ charging cycles, respectively. This indicates that the chemical composition of $\mathrm{Li}_{x} \mathrm{PO}_{y} \mathrm{~F}_{z}$ is close to $\mathrm{Li}_{3} \mathrm{PO}_{4}$, although the ${ }^{7} \mathrm{Li}$ signal may include some contributions from the other diamagnetic components as suggested later.

The Li content consumed for surface film formation can be estimated for the fully charged samples. Based on the ${ }^{7} \mathrm{Li}$ NMR spectrum taken with the sufficient relaxation delay of $20 \mathrm{~s}$ for the $51^{\text {st }}$-cycled fully charged $\mathrm{Li}_{x} \mathrm{FePO}_{4}$, the $\mathrm{Li}$ content remaining in the electrode was estimated to be $0.11 \mathrm{Li}$, and $0.05 \mathrm{Li}$ of which could be assigned to the diamagnetic lithium species. The diamagnetic lithium in the differential spectrum with the delay of $0.1 \mathrm{~s}$ and $20 \mathrm{~s}$ corresponds to 0.03 Li (Fig. 7). If we simply assume that the diamagnetic lithium component with the relaxation delay of $\leq 0.1 \mathrm{~s}$ is closely attached on the surface of the paramagnetic $\mathrm{Li}_{x} \mathrm{FePO}_{4}$, and that the remaining component with the longer delays $(>0.1 \mathrm{~s})$ is rather far from the surface, ${ }^{53}$ it may be possible to consider that only $0.02 \mathrm{Li}$ is closely attached on the surface of the active material, on which the other $0.03 \mathrm{Li}$ would be further deposited to form thicker film. Similar but more detailed discussion has been done by Dupré et al. ${ }^{53}$ Figs. 5 and 8 show that the ${ }^{7} \mathrm{Li}$ and ${ }^{31} \mathrm{P}$ signals for $\mathrm{Li}_{x} \mathrm{PO}_{y} \mathrm{~F}_{z}$, which were acquired with the relaxation delay of $0.1 \mathrm{~s}$, increase on charging processes. Based on the above assumption, this suggests that $\mathrm{Li}_{x} \mathrm{PO}_{y} \mathrm{~F}_{z}$ covers over the surface of the $\mathrm{Li}_{x} \mathrm{FePO}_{4}$ particles with multiple charging cycles, as well as its further deposition on the pre-existing film.

XPS measurements were performed as a surface-sensitive chemical state characterization to further investigate the surface layer on the electrodes. Fig. 9 shows the Fe 2p, O 1s, C 1s, and F 1s spectra for the $\mathrm{LiFePO}_{4}$ electrodes after 11 and 51 times charging and subsequent discharging along with the pristine and soaked electrodes. Fig. 9a shows the Fe 2 p spectra, which were split into two components $\left(\mathrm{Fe} 2 \mathrm{p}_{3 / 2}\right.$ and $\left.2 \mathrm{p}_{1 / 2}\right)$ with an intensity ratio of $2: 1$ due to spin-orbit coupling. ${ }^{54}$ The soaked and fully discharged electrodes have the $2 \mathrm{p}_{3 / 2}$ main peak at $\sim 710 \mathrm{eV}$, which is characteristic of $\mathrm{Fe}^{2+}$ valence state. On the other hand, the $2 \mathrm{p}_{3 / 2}$ peak was moved to higher binding energy at $712 \mathrm{eV}$ in the fully charged $\mathrm{Li}_{x} \mathrm{FePO}_{4}$, indicating that $\mathrm{Fe}^{3+}$ was the main component in the charged states. ${ }^{54} \mathrm{~A}$ small shoulder at $\sim 710 \mathrm{eV}$ may be the indication of remnant $\mathrm{Fe}^{2+}$ in the charged electrodes. These results on Fe $2 p$ were consistent with the observations from electrochemical and NMR measurements. The observation of $\mathrm{Fe}^{2+}$ or $\mathrm{Fe}^{3+}$ in $\mathrm{Li}_{x} \mathrm{FePO}_{4}$ suggests that the film covering on the surface of $\mathrm{Li}_{x} \mathrm{FePO}_{4}$ particles is thinner than the photoelectron escape depth $(<\sim 5 \mathrm{~nm})$ in the conventional XPS equipment. Alternatively, the surface may be covered in an inhomogeneous manner with thinner film on some parts and thicker one on the others.

O 1s core peak spectra were shown in Fig. 9b. A main peak at $531.3 \mathrm{eV}$ was assigned to the $\left[\mathrm{PO}_{4}\right]^{3-}$ phosphate species in $\mathrm{LiFePO}_{4}$ and $\mathrm{FePO}_{4}$. A shoulder at $\sim 533.5 \mathrm{eV}$ was considered due to the surface oxygenated species, probably $\mathrm{CO}$ groups as in polyethylene oxides (PEO), originating from the electrolyte decomposition. ${ }^{41}$ This shoulder became larger in the $51^{\text {st }}$-cycled samples, indicating the thicker deposition of the surface film during multiple cycling. C 1s core peak spectra for electrode samples show a main peak at $284.3 \mathrm{eV}$ due to acetylene black and carbon coated on $\mathrm{Li}_{x} \mathrm{FePO}_{4}$ particles, and two PVDF binder components at $\sim 286.0$ and $290.3 \mathrm{eV}$ (Fig. 9c). ${ }^{54}$ It was found that the $51^{\text {st }}$-cycled samples have higher intensity at $\sim 286.0 \mathrm{eV}$. This can be attributed to additional surface CO species, ${ }^{41,55}$ supporting the above $\mathrm{O} 1 \mathrm{~s}$ spectra. We note that the surface component observed in $\mathrm{O} 1 \mathrm{~s}$ and $\mathrm{C} 1 \mathrm{~s}$ spectra shows a different behavior from that observed in NMR. Fig. $9 \mathrm{~d}$ represents F 1s spectra of the electrode samples. A main peak at $687.4 \mathrm{eV}$ comes from the PVDF binder. ${ }^{54} \mathrm{~A}$ small shoulder characteristic of $\mathrm{LiF}$ was identified at $\sim 684.5 \mathrm{eV}$ for the soaked $\mathrm{LiFePO}_{4}$, charged and discharged $\mathrm{Li}_{x} \mathrm{FePO}_{4}$ samples. ${ }^{41,54}$ Our result suggested that the amount of $\mathrm{LiF}$, which was probably formed on soaking the electrode into electrolyte solution, remained almost constant up to the $51^{\text {st }}$-cycle. Such a small amount of $\mathrm{LiF}$ also gives a very small contribution to ${ }^{7} \mathrm{Li}$ diamagnetic signal. P $2 \mathrm{p}$ core spectra showed an asymmetric peak (combination of $2 \mathrm{p}_{3 / 2}$ and $2 \mathrm{p}_{1 / 2}$ peaks) characteristic of the $\left[\mathrm{PO}_{4}\right]^{3-}$ species in $\mathrm{LiFePO}_{4}$ and $\mathrm{FePO}_{4}$, which was totally identical in position and shape for all the samples and no evolutions were observed with charge-discharge cycles (not shown). We note that the formation of $\mathrm{Li}_{x} \mathrm{PO}_{y} \mathrm{~F}_{z}$, which was identified as a salt degradation product from the NMR results, was not confirmed from the XPS spectra probably because the $\mathrm{O} 1 \mathrm{~s}, \mathrm{P} 2 \mathrm{p}$, and $\mathrm{F} 1$ s core peaks of the minor $\mathrm{Li}_{x} \mathrm{PO}_{y} \mathrm{~F}_{z}$ phase are closely overlapped with those of main components $\mathrm{LiFePO}_{4} / \mathrm{FePO}_{4}$ and PVDF, respectively. ${ }^{41,54,55}$ The present XPS results were qualitatively consistent with the previous studies, ${ }^{41,54-56}$ and some differences observed among these XPS studies would depend on their sample preparation conditions.

The combination of NMR and XPS spectroscopies offers more comprehensive information about the surface film formation on active materials, which is summarized below and illustrated in Fig. 10. The initial surface film formed on the electrode with electrolyte solution immersion (without redox cycles) is composed of $\mathrm{LiF}$ that comes from the partial decomposition of $\mathrm{LiPF}_{6}$ salt (Fig. 10b). This inorganic film remains unchanged with respect to the subsequent 

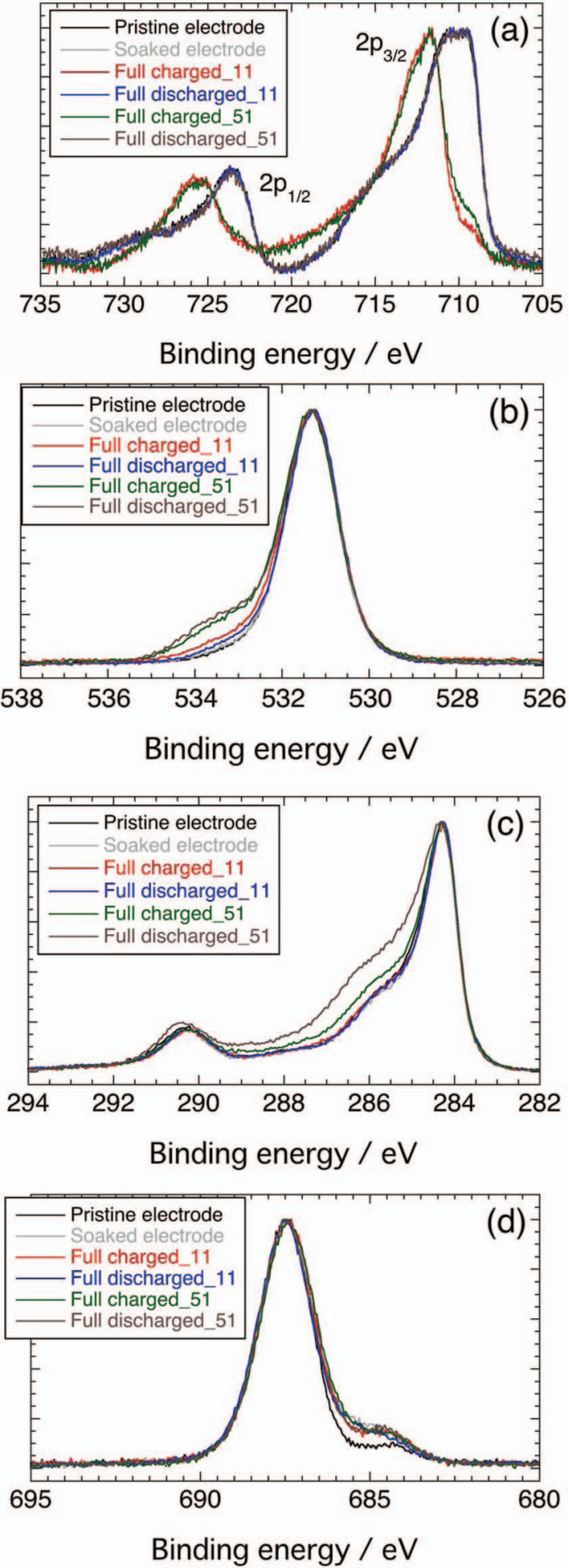

Figure 9. XPS spectra of the as-prepared and electrolyte-soaked $\mathrm{LiFePO}_{4}$ electrodes, and those disassembled on $11^{\text {th }}$ and $51^{\text {st }}$ electrochemical cycles; $\mathrm{Fe} 2 \mathrm{p}$ (a), O 1s (b), C 1s (c), and F 1s (d). Intensities are normalized at main peaks.

electrochemical processes. The $\mathrm{Li}_{x} \mathrm{PO}_{y} \mathrm{~F}_{z}$ film is then formed in the initial charging processes on the $\mathrm{LiF}$ layer (Fig. 10c), which is considered to be again derived from the degradation of $\mathrm{LiPF}_{6}$ salt in the electrolyte solution. Its film thickness seems to gradually increase on multiple charging cycles whereas the film once shrinks during (a)

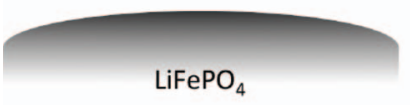

(c)
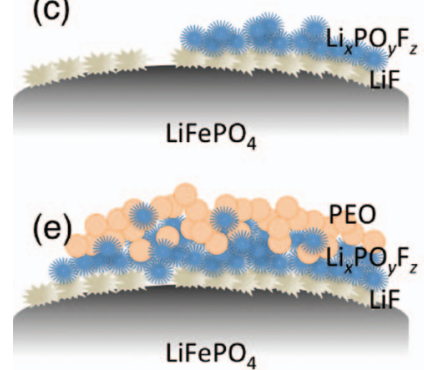

(b)

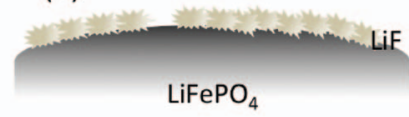

(d)
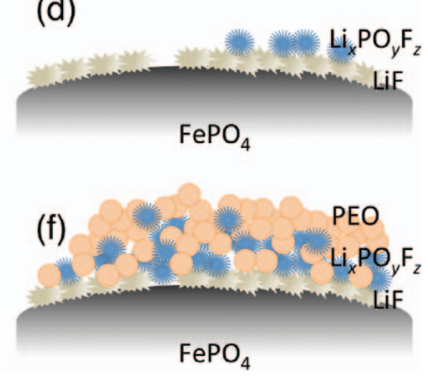

Figure 10. A schematic illustration of the surface film formation on a $\mathrm{Li}_{x} \mathrm{FePO}_{4}$ particle based on the observation of NMR and XPS; (a) pristine electrode, (b) soaked electrode, (c) charged at $1^{\text {st }}$ cycle, (d) discharged at $1^{\text {st }}$ cycle, (e) charged at $51^{\text {st }}$ cycle, and (f) discharged at $51^{\text {st }}$ cycle, respectively.

discharging (Fig. 10d), which suggests the dynamic behavior of the $\mathrm{Li}_{x} \mathrm{PO}_{y} \mathrm{~F}_{z}$ phase, namely, its formation at high potential and dissolution into the electrolyte at low potential. After multiple cycles the electrolyte solvent decomposition proceeds and an organic film component, considered to be PEO, is formed (Fig. 10e). The $\mathrm{Li}_{x} \mathrm{PO}_{y} \mathrm{~F}_{z}$ dissolution still proceeds after the PEO formation (Fig. 10f), suggesting the porous nature of the PEO film. The small capacity loss observed after 30 cycles (Fig. 1) can be related to the formation of PEO as a resistive film for $\mathrm{Li}^{+}$ion conduction, while the $\mathrm{Li}_{x} \mathrm{PO}_{y} \mathrm{~F}_{z}$ phase seems not to contribute to the fading behavior because it continuously increases from the initial charging steps. We believe that the formation of the surface film consisting of organic components plays an important role as a key factor of capacity fading with respect to electrochemical cycles.

\section{Conclusions}

We carried out an intensive characterization of both bulk and surface chemical states for the electrochemically cycled $\mathrm{LiFePO}_{4}$ electrodes by using ${ }^{7} \mathrm{Li}$ and ${ }^{31} \mathrm{P}$ MAS NMR spectroscopy. ${ }^{7} \mathrm{Li}$ MAS NMR confirmed the quantitative lithium extraction from $\mathrm{LiFePO}_{4}$ on electrochemical operation. The two-phase reaction behavior between $\mathrm{LiFePO}_{4}$ and $\mathrm{FePO}_{4}$ was reversibly observed on ${ }^{31} \mathrm{P}$ MAS NMR spectra. The ${ }^{7} \mathrm{Li}$ spectra of the fully charged $\mathrm{Li}_{x} \mathrm{FePO}_{4}$ samples showed a small amount of $\mathrm{Li}$ influenced by $\mathrm{Fe}^{3+}$ in the host structure, strongly suggesting that the ${ }^{7} \mathrm{Li}$ signal represents the end-member solid solution $\mathrm{Li}_{0.05} \mathrm{FePO}_{4}$ instead of $0.05 \mathrm{LiFePO}_{4}$. The NMR spectra of the $\mathrm{LiFePO}_{4}$ electrodes cycled up to 51 times indicated the stability of the local environments around $\mathrm{Li}$ and $\mathrm{P}$ atoms, which would be a reason of its good cycle performance.

NMR and XPS provided complementary information about the behavior of surface film on positive electrode. The formation of $\mathrm{Li}_{x} \mathrm{PO}_{y} \mathrm{~F}_{z}$ was considered from the NMR results. This phase continuously grows with multiple charge-discharge cycles, where it increases on charging but decreases on subsequent discharging. On the other hand, the alternative XPS study revealed the presence of $\mathrm{CO}$ species, which are attributable to the organic derivatives such as PEO, coming from the degradation of electrolyte solvent. The organic derivatives deposit after increasing the cycle number. The combination of NMR and XPS surface characterization suggests that the degradation of $\mathrm{LiPF}_{6}$ salt occur from initial redox cycles but that of solvent occur after multiple cycling, and the formation of the surface film consisting of organic species would lead to capacity fading after the multiple charge-discharge cycles. 


\section{Acknowledgments}

This work was supported by the Research and Development Innovative for Scientific Innovation of New Generation Battery (RISING) project from New Energy and Industrial Technology Development Organization (NEDO), Japan. The authors thank Takahiro Kakei for his supports on electrochemical sample preparations.

\section{References}

1. A. K. Padhi, K. S. Nanjundaswamy, and J. B. Goodenough, J. Electrochem. Soc., 144, 1188 (1997).

2. P. Gibot, M. Casas-Cabanas, L. Laffont, S. Levasseur, P. Carlach, S. Hamelet, J.-M. Tarascon, and C. Masquelier, Nat. Mater., 7, 741 (2008).

3. B. Kang and G. Ceder, Nature, 458, 190 (2009).

4. S. Hamelet, P. Gibot, M. Casas-Cabanas, D. Bonnin, C. P. Grey, J. Cabana, J.-B. Leriche, J. Rodriguez-Carvajal, M. Courty, S. Levasseur, P. Carlach, M. van Thournout, J.-M. Tarascon, and C. Masquelier, J. Mater. Chem., 19, 3979 (2009).

5. L.-X. Yuan, Z.-H. Wang, W.-X. Zhang, X.-L. Hu, J.-T. Chen, Y.-H. Huang, and J. B. Goodenough, Energy Environ. Sci., 4, 269 (2011).

6. Z. Gong and Y. Yang, Energy Environ. Sci., 4, 3223 (2011)

7. D. Kim, J. Lim, V. Mathew, B. Koo, Y. Paik, D. Ahn, S.-M. Paek, and J. Kim, J. Mater. Chem., 22, 2624 (2012).

8. R. Malik, A. Abdellahi, and G. Ceder, J. Electrochem. Soc., 160, A3179 (2013)

9. A. S. Andersson, B. Kalska, L. Haggstrom, and J. O. Thomas, Solid State Ionics, 130, 41 (2000).

10. N. Ravet, Y. Chouinard, J. F. Magnan, S. Besner, M. Gauthier, and M. Armand, J. Power Sources, 97-98, 503 (2001).

11. R. Dominko, M. Gaberšček, J. Drofenik, M. Bele, and S. Pejovnik, Electrochem Solid-State Lett., 4, A187 (2001).

12. A. Yamada, S. C. Chung, and K. Hinokuma, J. Electrochem. Soc., 148, A224 (2001)

13. C. Delacourt, P. Poizot, S. Levasseur, and C. Masquelier, Electrochem. Solid-State Lett., 9, A352 (2006).

14. M. Gaberscek, R. Dominko, and J. Jamnik, Electrochem. Commun., 9, 2778 (2007).

15. A. Deb, U. Bergmann, E. J. Cairns, and S. P. Cramer, J. Synchrotron Rad., 11, 497 (2004).

16. K. Inoue, S. Fujieda, K. Shinoda, S. Suzuki, and Y. Waseda, Mater. Trans., 51, 2220 (2010).

17. X.-J. Wang, C. Jaye, K.-W. Nam, B. Zhang, H.-Y. Chen, J. Bai, H. Li, X. Huang, D. A. Fischer, and X.-Q. Yang, J. Mater. Chem., 21, 11406 (2011).

18. A. Yamada, H. Koizumi, S. Nishimura, N. Sonoyama, R. Kanno, M. Yonemura, T. Nakamura, and Y. Kobayashi, Nat. Mater, 5, 357 (2006).

19. G. Kobayashi, S. Nishimura, M.-S. Park, R. Kanno, M. Yashima, T. Ida, and A. Yamada, Adv. Funct. Mater, 19, 395 (2009).

20. N. Meethong, H.-Y. S. Huang, W. C. Carter, and Y.-M. Chiang, Electrochem. Solid-S tate Lett., 10, A134 (2007).

21. C. Delacourt, P. Poizot, J.-M. Tarascon, and C. Masquelier, Nat. Mater, 4, 254 (2005)

22. K. R. Morgan, S. Collier, G. Burns, and K. Ooi, J. Chem. Soc. Chem. Commun., 1719 (1994).

23. C. Marichal, J. Hirschinger, P. Granger, M. Ménétrier, A. Rougier, and C. Delmas, Inorg. Chem., 34, 1773 (1995).

24. P. Mustarelli, V. Massarotti, M. Bini, and D. Capsoni, Phys. Rev. B, 55, 12018 (1997)

25. M. P. J. Peeters, M. J. van Bommel, P. M. C. Neilen-en Wolde, H. A. M. van Hal, W. C. Keur, and A. P. M. Kentgens, Solid State Ionics, 112, 41 (1998).

26. M. Ménétrier, I. Saadoune, S. Levasseur, and C. Delmas, J. Mater. Chem., 9, 1135 (1999).
27. V. W. J. Verhoeven, I. M. de Schepper, G. Nachtegaal, A. P. M. Kentgens, E. M. Kelder, J. Schoonman, and F. M. Mulder, Phys. Rev. Lett., 86, 4314 (2001).

28. M. C. Tucker, M. M. Doeff, T. J. Richardson, R. Fiñones, E. J. Cairns, and J. A. Reimer, J. Am. Chem. Soc., 124, 3832 (2002).

29. C. P. Grey and Y. J. Lee, Solid State Sci., 5, 883 (2003).

30. C. P. Grey and N. Dupré, Chem. Rev., 104, 4493 (2004).

31. M. Ménétrier, J. Bains, L. Croguennec, A. Flambard, E. Bekaert, C. Jordy, P. Biensan, and C. Delmas, J. Solid State Chem., 181, 3303 (2008).

32. G. Mali, M. Rangus, C. Sirisopanaporn, and R. Dominko, Solid State Nucl. Magn. Reson., 42, 33 (2012).

33. K. Shimoda, M. Murakami, D. Takamatsu, H. Arai, Y. Uchimoto, and Z. Ogumi, Electrochim. Acta, 108, 343 (2013).

34. M. Ménétrier, C. Vaysse, L. Croguennec, C. Delmas, C. Jordy, F. Bonhomme, and P. Biensan, Electrochem. Solid-State Lett., 7, A140 (2004).

35. B. M. Meyer, N. Leifer, S. Sakamoto, S. G. Greenbaum, and C. P. Grey, Electrochem. Solid-State Lett., 8, A145 (2005).

36. N. Dupré, J. Oliveri, J. Degryse, J.-F. Martin, and D. Guyomard, Ionics, 14, 203 (2008).

37. M. Murakami, H. Yamashige, H. Arai, Y. Uchimoto, and Z. Ogumi, Electrochem. Solid-State Lett., 14, A134 (2011).

38. N. Dupré, J.-F. Martin, J. Oliveri, P. Soudan, A. Yamada, R. Kanno, and D. Guyomard, J. Power Sources, 196, 4791 (2011).

39. M. Cuisinier, J.-F. Martin, P. Moreau, T. Epicier, R. Kanno, D. Guyomard, and N. Dupré, Soild State Nucl. Magn. Reson., 42, 51 (2012).

40. M. Murakami, H. Yamashige, H. Arai, Y. Uchimoto, and Z. Ogumi, Electrochim. Acta, 78, 49 (2012).

41. M. Cuisinier, N. Dupré, J.-F. Martin, R. Kanno, and D. Guyomard, J. Power Sources, 224, 50 (2013).

42. J. Cabana, J. Shirakawa, G. Chen, T. J. Richardson, and C. P. Grey, Chem. Mater, 22, 1249 (2010)

43. L. J. M. Davis, I. Heinmaa, B. L. Ellis, L. F. Nazar, and G. R. Goward, Phys. Chem. Chem. Phys., 13, 5171 (2011).

44. S. L. Wilcke, Y. J. Lee, E. J. Cairns, and J. A. Reimer, Appl. Magn. Reson., 32, 547 (2007).

45. J. Kim, D. S. Middlemiss, N. A. Chernova, B. Y. X. Zhu, C. Masquelier, and C. P. Grey, J. Am. Chem. Soc., 132, 16825 (2010).

46. R. J. Clément, A. J. Pell, D. S. Middlemiss, F. C. Strobridge, J. K. Miller, M. S. Whittingham, L. Emsley, C. P. Grey, and G. Pintacuda, J. Am. Chem. Soc., 134, 17178 (2012).

47. L. Gu, C. Zhu, H. Li, Y. Yu, C. Li, S. Taukimoto, J. Maier, and Y. Ikuhara, J. Am. Chem. Soc., 133, 4661 (2011).

48. C. Delmas, M. Maccario, L. Croguennec, F. Le Cras, and F. Weill, Nat. Mater, 7, 665 (2008).

49. W.-S. Yoon, K. Y. Chung, J. McBreen, K. Zaghib, and X.-Q. Yang, Electrochem. Solid-State Lett., 9, A415 (2006).

50. Y. J. Lee, F. Wang, S. Mukerjee, J. McBreen, and C. P. Grey, J. Electrochem. Soc., 147, $803(2000)$

51. A. V. Plakhotnyk, L. Ernst, and R. Schmutzler, J. Fluorine Chem., 126, 27 (2005).

52. C. L. Campion, W. Li, and B. L. Lucht, J. Electrochem. Soc., 152, A2327 (2005).

53. N. Dupré, J.-F. Martin, D. Guyomard, A. Yamada, and R. Kanno, J. Mater. Chem., 18, 4266 (2008).

54. R. Dedryvère, M. Maccario, L. Croguennec, F. Le Cras, C. Delmas, and D. Gonbeau, Chem. Mater, 20, 7164 (2008)

55. L. Castro, R. Dedryvère, J.-B. Ledeuil, J. Bréger, C. Tessier, and D. Gonbeau, J. Electrochem. Soc., 159, A357 (2012).

56. M. Herstedt, M. Stjerndahl, A. Nytén, T. Gustafsson, H. Rensmo, H. Siegbahn, N. Ravet, M. Armand, J. O. Thomas, and K. Edström, Electrochem. Solid-State Lett., 6. A202 (2003). 